\title{
DIASTOLIC DYSFUNCTION IN CASES WITH TYPE II DIABETES MELLITUS.
}

\author{
1. MBBS, FCPS \\ Senior Registrar \\ Department of Medicine \\ Muhammad Medical College \\ Mirpurkhas. \\ 2. MBBS, FCPS \\ Senior Registrar \\ Department of Medicine \\ Khairpur Medical College Khairpur. \\ 3. MBBS, FCPS \\ Assistant Professor \\ Department of Obstetrics and \\ Gynecology \\ Shaheed Motharma Benazir Bhutto \\ Medical College Liyari Karachi. \\ 4. MBBS, DMJ \\ Assistant Professor \\ Department of Forensic Medicine \\ Khairpur Medical College Khairpur. \\ 5. MBBS \\ Medical Officer \\ Department of Medicine \\ Khairpur Medical College Khairpur. \\ Correspondence Address: \\ Dr. Munir Ahmed \\ Noor Clinic and Maternity Home, \\ Mirzapur Mohalla Kandhkot \\ District Kandhkot Sindh. \\ drmunirchanna@yahoo.com \\ Article received on: \\ 18/10/2018 \\ Accepted for publication: \\ 09/04/2019
}

\section{INTRODUCTION}

Diabetes Mellitus (DM) is one of the highest prevalent metabolic syndrome worldwide and its number is highest in the developed world. It has two major types i.e. type I and type II DM depending upon the time of onset and insulin deficiency and resistance pattern. The data is lacking in the developing countries, but scarce findings revealed that the number is increasing gradually attributed to change in the life style., ${ }^{1,2}$

Diabetes Mellitus leads to chronic hyperglycemic levels that can affect the body in various ways when uncontrolled. It can virtually involve any part of the body and the complications are majorly sub divided into micro and macro-vascularbased due to underlying atherosclerosis of the blood vessels. Cardiovascular system (CVS) can be affected most in cases with un-controlled DM, that can further increase the symptomatology in such cases. ${ }^{2,3}$ Cardiac complications include acute coronary syndromes, cardiac arrhythmias, systolic and diastolic dysfunctions, cardiomyopathy etc. The data has revealed that around $65 \%$ of the cases suffering from DM die due to an insulting cardiac event. ${ }^{4-6}$

Diastolic dysfunction is under extensive discussion in the recent times and seems to effect earlier as compared to the systolic dysfunction. Electrocardiogram (ECG) is nonspecific for detection of this and trans thoracic echocardiography is the tool of choice and E/A ratio is indicative to label diastolic dysfunction. ${ }^{7-9}$ Sharavanan et al, in their study, irrespective of the type of DM carried echo to look for diastolic dysfunction and it was seen in $55 \%$ of cases. ${ }^{8}$ In other studies done by Sridevi\& Dikshit et al, found this in $65-80 \%$ of the cases suffering from DM. ${ }^{6}$ Systolic dysfunction is still being the most 
studied in the under developed countries; that's why this study was planned to document the burden of the diastolic dysfunction in such cases so that further steps can be taken to early predict and manage such cases.

\section{MATERIALS AND METHODS}

This cross sectional study was carried out at Sheikh Zayed Hospital, Rahim Yar Khan during 01-01-2017 to 30-06-2017. In this study the cases were selected via non probability consecutive sampling. The cases of both male and female gender with age more than 40 years having type II DM of at least more than 2 years were included. The cases suffering from type I DM, gestational DM and those with HTN, end stage kidney and liver failure were excluded. The cases were selected from the medical out-patient department and were sent for trans thoracic echocardiography to the Cardiology department of the same institute and the echo was done by a consultant cardiologist with at least more than 1 year experience post fellowship. On echocardiography, the diastolic dysfunction was labelled as yes when the E/A ratio was $<0.8$. The data was analysed using SPSS version 22. The numerical data was presented as mean and standard deviation whiles the categorical data as frequencies and percentages. The effect modifiers like age, gender and BMI were controlled through stratification and post stratification chi-square test was applied taking $\mathrm{p}$ value $<0.05$ as significant.

\section{RESULTS}

In this study, 100 cases of type II DM were included with mean age of $51.31 \pm 7.89$ years at presentation. There were $61 \%$ males and $39 \%$ females. Diastolic dysfunction was observed in $53 \%$ of the cases (Figure-1). There was no significant difference in terms of gender where it affected $56.41 \%$ of females with $p=0.92$ as in Table-I. Diastolic dysfunction was more in cases that had duration of DM more than 3 years affecting $70.58 \%$ cases Table-II with $p=0.001$ and it was also significantly high in cases that had BMI more than 30 where it was seen in $70.17 \%$ of cases with $p=0.001$ as displayed in Table-III.

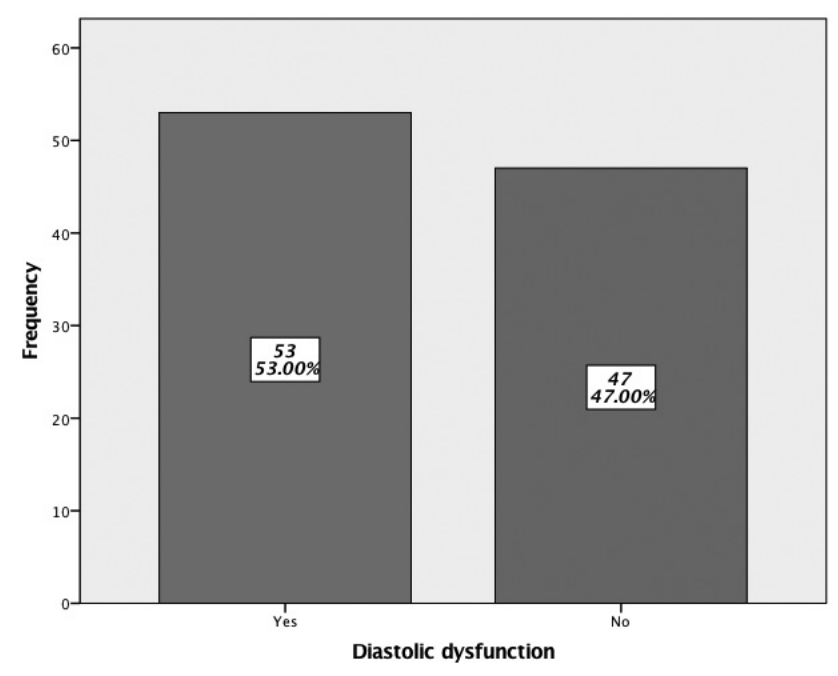

Figure-1. Diastolic dysfunction

\begin{tabular}{|c|c|c|c|c|}
\hline \multirow{2}{*}{ Gender } & \multicolumn{2}{|c|}{$\begin{array}{c}\text { Diastolic } \\
\text { Dysfunction }\end{array}$} & \multirow[t]{2}{*}{ Total } & \multirow{2}{*}{ P-Value } \\
\hline & Yes & No & & \\
\hline Male & $\begin{array}{c}31 \\
(50.81 \%)\end{array}$ & $\begin{array}{c}30 \\
(49.19 \%)\end{array}$ & $\begin{array}{c}61 \\
(100 \%)\end{array}$ & \\
\hline Female & $\begin{array}{c}22 \\
(56.41 \%)\end{array}$ & $\begin{array}{c}17 \\
(43.59 \%)\end{array}$ & $\begin{array}{c}39 \\
(100 \%)\end{array}$ & 0.092 \\
\hline Total & $53(53 \%)$ & 47 (47\%) & $\begin{array}{c}100 \\
(100 \%)\end{array}$ & \\
\hline
\end{tabular}

Table-I. Diastolic dysfunction and gender

\begin{tabular}{|l|c|c|c|c|}
\hline $\begin{array}{l}\text { Duration } \\
\text { of DM }\end{array}$ & \multicolumn{2}{|c|}{$\begin{array}{c}\text { Diastolic } \\
\text { Dysfunction }\end{array}$} & Total & P-Value \\
\hline \begin{tabular}{l|c|c|c|} 
Yes \\
years
\end{tabular} & $\begin{array}{c}48 \\
(70.58 \%)\end{array}$ & $\begin{array}{c}20 \\
(29.42 \%)\end{array}$ & $\begin{array}{c}68 \\
(100 \%)\end{array}$ & \\
\hline 3 or less & 5 & 27 & 32 & 0.001 \\
\hline Total & $(15.62 \%)$ & $(84.38 \%)$ & $(100 \%)$ & 0.00 \\
\hline
\end{tabular}

Table-II. Diastolic dysfunction and length of DM

\begin{tabular}{|c|c|c|c|c|}
\hline \multirow[t]{2}{*}{ BMI } & \multicolumn{2}{|c|}{$\begin{array}{c}\text { Diastolic } \\
\text { Dysfunction }\end{array}$} & \multirow[t]{2}{*}{ Total } & \multirow[t]{2}{*}{ P-Value } \\
\hline & Yes & No & & \\
\hline$>30$ & $\begin{array}{c}40 \\
(70.17 \%)\end{array}$ & $\begin{array}{c}17 \\
(29.83 \%)\end{array}$ & $\begin{array}{c}57 \\
(100 \%)\end{array}$ & $>30$ \\
\hline$<30$ & $\begin{array}{c}13 \\
(30.23 \%)\end{array}$ & $\begin{array}{c}30 \\
(69.77 \%)\end{array}$ & $\begin{array}{c}43 \\
(100 \%)\end{array}$ & $<30$ \\
\hline Total & $53(53 \%)$ & 47 (47\%) & $\begin{array}{c}100 \\
(100 \%)\end{array}$ & Total \\
\hline
\end{tabular}

Table-III. Diastolic dysfunction and BMI

\section{DISCUSSION}

Typell Diabetes Mellitus is caused by the resistance of the tissue to the produced insulin and lead to chronic hyper glycaemia and decreased uptake of the glucose by the cells. This persistent hyper 
glycaemia lead to wide range of complications in the cardiovascular system due to atherosclerosis and cardiomyopathies. ${ }^{9,10}$

In the present study Diastolic dysfunction (DD) was seen in $53 \%$ of cases having type II DM. This results were close the previous studies carried out on cases of DM. Sharanavan et al, carried out a similar study and it was seen that this dysfunction was seen in 66 (55\%) cases in their study. ${ }^{10}$ The study by Patil et al also strengthened the results of the present study, where they found54.33\% of their cases having DM to be affected by Diastolic dysfunction. ${ }^{11}$

In the present study DD was seen significantly high in cases that had BMI more than 30 where it was seen in $70.17 \%$ of cases with $p=0.001$. The data from the previous studies have also shown that the high BMI is an independent risk factor to develop diastolic dysfunction. ${ }^{12,13}$ Germing A et al carried out a case control trial to look for DD in cases with and without DM and it was seen that this was significantly high in cases that had DM $(p<0.05) \cdot{ }^{14}$ Russo, et al in another study also found this to be significantly associated with not only DM but also found a positive correlation between the length of DM and diastolic dysfunction. ${ }^{15}$

Diastolic dysfunction was also seen significantly in cases that had duration of DM more than 3 years affecting $70.58 \%$ cases with $p=0.001$. This finding was consistent with the study by Kumar et al; although they did not use the same cut off value, but it was seen that the cases with longer duration of DM has significantly high diastolic dysfunction with $p$ value of $0.03 .^{16}$

There were few limitations of this study as this study did not look for other confounding variables like HTN, Dyslipidemias and family history of cardiac disorders.

\section{CONCLUSION}

Diastolic dysfunction seen in half of the cases suffering from type II DM and it is significantly high in cases that had duration of DM more than 3 years and BMI more than 30 . Copyright 09 Apr, 2019.

\section{REFERENCES}

1. Fontes-Carvalho $R$, Ladeiras-Lopes $R$, Bettencourt $P$, Leite-Moreira A, Azevedo A. Diastolic dysfunction in the diabetic continuum: Association with insulin resistance, metabolic syndrome and type 2 diabetes. Cardiovasc Diabetol. 2015; 14(4):1-9.

2. Chaudhary AK, Aneja GK, Shukla S, Razi SM. Study on diastolic dysfunction in newly diagnosed Type 2 diabetes mellitus and its correlation with glycosylated haemoglobin (HbA1C). J Clin Diag Res. 2015; 9(8):OC20-OC22.

3. Yuankai S, Hu Frank B. The global implications of diabetes and cancer. The Lancet. 2014; 383(9933): 1947-48.

4. Sridevi, Jain R, Patil R. Assessment of left ventricular diastolic dysfunction by doppler echocardiography in patients of diabetes mellitus. Ind $\mathrm{J}$ Basic Applied Med Res. 2015:4(2):568-70.

5. Patil VC, Patil HV, Shah KB, Vasani JD, Shetty P. Diastolic function in asymptomatic type 2 diabetes mellitus with normal systolic function. J Cardiovascular Dis Res. 2011; 2(4):213-22.

6. Kazik A, Wilczek K, Poloski L. Management of diastolic heart failure. Cardiol J. 2010; 17:558-65.

7. Jain K, Palange AA, LalKakrani A, Dhanorkar AS. Left ventricular diastolic dysfunction in asymptomatic type 2 diabetes mellitus patients. Int J Res Med Sci 2018; 6:240-6.

8. Rubler S, Deluges J, Yuceoglu YZ, Kumar T, Branwood AW, Grishman A. New type of cardiomyopathy associated with diabetic glomerulosclerosis. Am J Cardiol. 1972; 30:595-602.

9. Senthil N, Vengadakrishnan K, Vankineni SS, Sujatha S. Diastolic Dysfunction in Young Asymptomatic Diabetics Patients. Int J Sci Stud. 2015; 3(7):226-229.

10. Sharavanan TKV, Prasanna KB, Ekanthalingam S, Sundaram A, Premalatha E, Arumugam B. A study on the prevalence of diastolic dysfunction in type 2 diabetes mellitus in a tertiary care hospital. Int Arch Integ Med. 2016; 3(7):216-21.

11. Patil MB, Burji NP. Echocardiographic evaluation of diastolic dysfunction in asymptomatic type 2 diabetes mellitus. J Assoc Physicians Ind. 2012; 60:23-26.

12. Dikshit NM, Wadia PZ, Shukla DK. Diastolic dysfunction in diabetes mellitus. Nat J Med Res. 2013; 3(3):249-52. 
13. VirendraC.Patil, Harsha V.Patil, Kuldeep B. Shah, Jay D. Vasani, Pruthvi Shetty. Diastolic dysfunction in asymptomatic type 2 diabetes mellitus with normal systolic function. J Cardiovasc Dis Res, 2011; 2 $(4): 213-222$.

14. Germing A, Gotzmann M, Schikowski S, Vierkotter A. Diastolic dysfunction without abnormalities in left atrial and left ventricular geometry does not affect quality of life in elderly women. Exp Clin Cardiol, $2011 ; 16(2): 37-39$.
15. Russo C, Jin Z, Homma S, Rundek T, Elkind MS, Sacco $R L$ et al. Effect of obesity and overweight on left ventricular diastolic function: a community-based study in an elderly cohort. J Am Coll Cardiol., 2011; 57:1368-76

16. Kumar A, Girish Kumar, Aneja, Shubhra Shukla, Syed Mohd Razi. Study on diastolic dysfunction in newly diagnosed Type 2 diabetes mellitus and its correlation with glycosylated haemoglobin (HbA1C). Journal of Clinical and Diagnostic Research, 2015; 9(8):OC20-OC22.

\begin{tabular}{|c|l|l|l|}
\hline \multicolumn{3}{|c}{ AUTHORSHIP AND CONTRIBUTION DECLARATION } \\
\hline Sr. \# & \multicolumn{1}{|c|}{ Author(s) Full Name } & \multicolumn{1}{|c|}{ Contribution to the paper } & Author(s) Signature \\
\hline 1 & Munir Ahmed Channa & $\begin{array}{l}\text { Data collcetion and retionable } \\
\text { setting, Plagiarism setting. } \\
\text { Data collection and } \\
\text { Methodology setting. } \\
\text { Discussion writing. }\end{array}$ \\
\hline 3 & Abdul Hayee & Shahla Afsheen & $\begin{array}{l}\text { References setting, searching } \\
\text { of literature and review of } \\
\text { manuscript. } \\
\text { Introeudtion writing and }\end{array}$ \\
\hline 5 & Abdul Qayoom Memon & \\
\hline Abstract writing.
\end{tabular}

